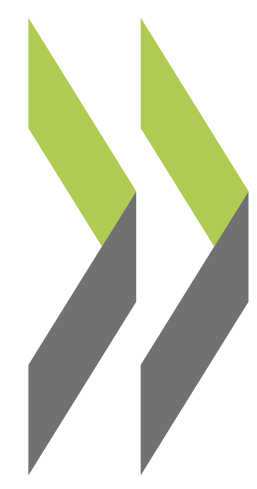

OECD Economics Department Working Papers No. 931

\title{
Less Income Inequality and More Growth - Are they Compatible? Part 8 . The Drivers of Labour Income Inequality - A Literature Review
} Rafal Kierzenkowski, 
Organisation de Coopération et de Développement Économiques

Organisation for Economic Co-operation and Development

03-Apr-2012

ECONOMICS DEPARTMENT

English - Or. English

LESS INCOME INEQUALITY AND MORE GROWTH - ARE THEY COMPATIBLE?
PART 8. THE DRIVERS OF LABOUR INCOME INEQUALITY - A LITERATURE REVIEW

ECONOMICS DEPARTMENT WORKING PAPER No. 931

by Rafal Kierzenkowski and Isabell Koske

All Economics Department Working Papers are available through OECD's internet website at www.oecd.org/eco/workingpapers

JT03319072

Complete document available on OLIS in its original format

This document and any map included herein are without prejudice to the status of or sovereignty over any territory, to the delimitation of international frontiers and boundaries and to the name of any territory, city or area. 


\section{ABSTRACT/RESUMÉ \\ Less income inequality and more growth - Are they compatible? \\ Part 8. The drivers of labour income inequality - A literature review}

Despite a general trend of increasing labour income inequality, there have been differences in the timing, intensity and even direction of these changes across OECD countries. These stylized facts have led to numerous studies about the main determinants of labour income inequality and, as a result, a significant revision of the previous consensus about the key drivers. The most researched channels include skill-biased technological change, international trade, immigration, education as well as the role of labour market policies and institutions.

JEL classification codes: D63; F16; I24; J31; J58; O33

Keywords: Income inequality; labour income; globalisation; trade; immigration; technological change; education policy; labour market policy.

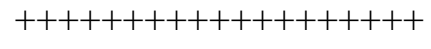

Moins d'inégalités de revenu et plus de croissance - Ces deux objectifs sont-ils compatibles?

Partie 8. Les déterminants de l’inégalité de revenu du travail - une revue de la littérature

En dépit d'une tendance générale à l'augmentation des inégalités de revenu du travail, des différences sont apparues quant à l'occurrence, l'intensité et même le sens de ces évolutions au sein des pays de l'OCDE. Ces faits stylisés ont mené à de nombreuses études consacrées aux facteurs principaux de l'inégalité de revenu du travail et, en conséquence, d'une révision significative du consensus précédent concernant les déterminant clés. Les canaux les plus recherchés incluent le progrès technique, le commerce international, l'immigration, l'éducation ainsi que le rôle des politiques du marché du travail et des institutions.

Classification JEL : D63 ; F16 ; I24 ; J31 ; J58 ; O33

Mots clés : Inégalité de revenu ; revenu du travail ; mondialisation ; commerce ; immigration ; progrès technique ; politique d'éducation; politique du marché du travail. 


\section{TABLE OF CONTENTS}

\section{LESS INCOME INEQUALITY AND MORE GROWTH - ARE THEY COMPATIBLE? \\ PART 8. THE DRIVERS OF LABOUR INCOME INEQUALITY - A LITERATURE REVIEW...............5}

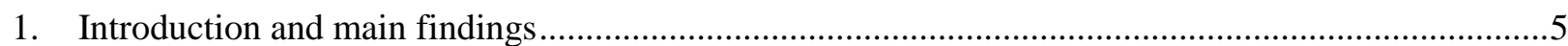

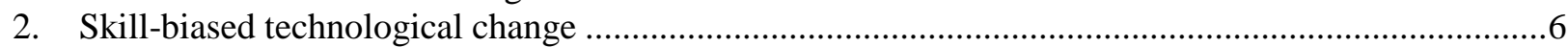

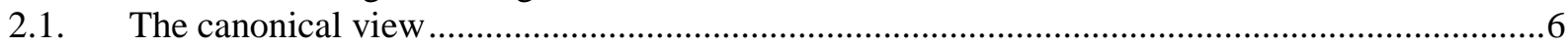

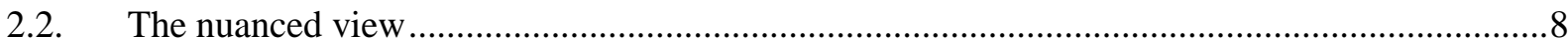

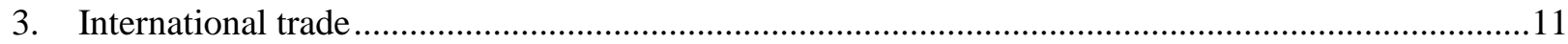

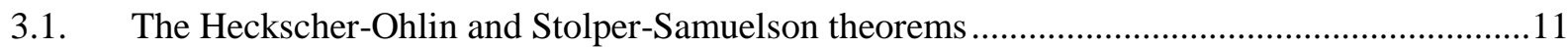

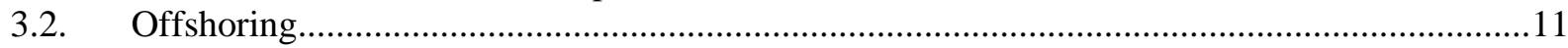

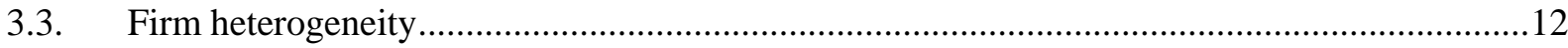

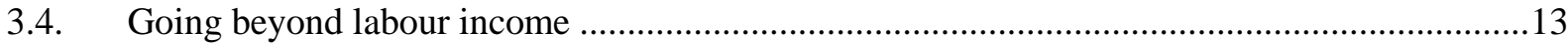

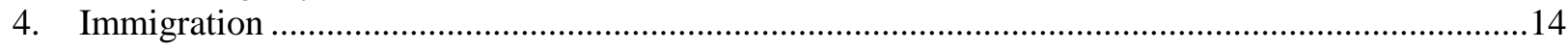

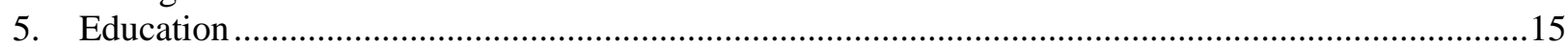

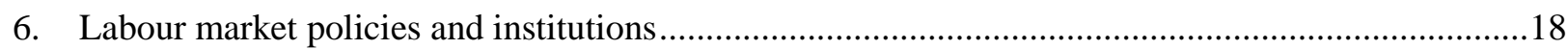

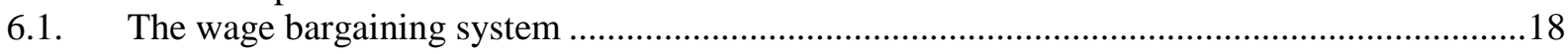

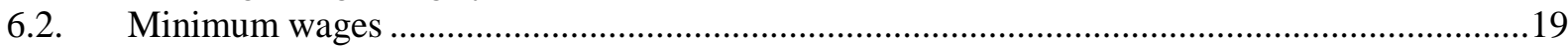

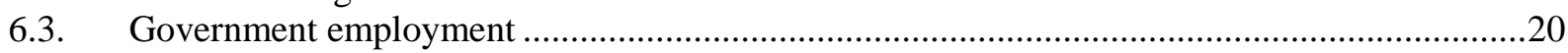

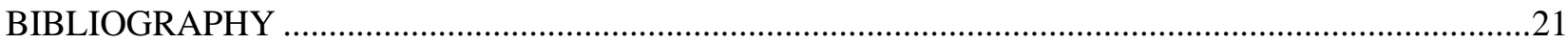


ECO/WKP(2012)8 
ECO/WKP(2012)8

LESS INCOME INEQUALITY AND MORE GROWTH - ARE THEY COMPATIBLE?

PART 8. THE DRIVERS OF LABOUR INCOME INEQUALITY - A LITERATURE REVIEW

by Rafał Kierzenkowski and Isabell Koske ${ }^{1}$

\section{Introduction and main findings}

In the early 1990s, there was a wide consensus in the US literature that (Lemieux, 2008): $i$ ) there had been a pronounced growth in inequality in the 1980s; ii) the main determinant behind widening inequality was an increase in the relative demand for skills driven by skill-biased technological change; iii) the relative demand for skills was pervasive or ubiquitous in the sense that all dimensions of inequality were growing (linked to returns to education, experience, unobserved ability, etc.); and iv) alternative explanations related to international trade or globalisation were not the main source of the increase in the relative demand for skills.

This consensus proved to be difficult to reconcile with the stylized facts of the 1990s and early 2000s, however. This includes in particular: $i$ ) the diverging patterns in inequality across advanced countries with, for instance, large and sustained increases in the United States and Germany and a narrowing distribution in France; and ii) an increasingly heterogeneous pattern of wage inequality at different points of the distribution over time. For example, in the case of the United States, inequality at the top end of the distribution has grown steadily since the 1980s, while at the low end it only widened in the 1980s and remained constant or declined during the 1970s, 1990s and 2000s. These new stylized facts led to a renewed interest in the drivers of labour income inequality and in particular the role of institutional and policy factors.

This paper provides an overview of the recent findings in the literature on the determinants of labour income inequality. The following main conclusions emerge from the analysis:

- Skill-biased technological change (canonical view): An important explanatory factor of increases in wage inequality at the top half of the distribution occurred through rising returns to skills over the last three decades in the US, but this channel fails to explain why inequality has diminished at the bottom relative to the median of the occupational skill distribution in OECD labour markets since the late 1980s as well as why within-group wage dispersion has grown substantially and mainly for college-educated workers.

- Skill-biased technological change (nuanced view): This strand explains why OECD labour markets have become polarised, with computer technology depressing the middle of the wage

1. The authors are members of the Economics Department of the OECD. This is one of the background papers for the OECD's project on Income Distribution and Growth-enhancing Policies. The authors would like to thank Jørgen Elmeskov, Jean-Luc Schneider, Peter Hoeller and Isabelle Joumard for their useful comments and suggestions and Susan Gascard for her excellent editorial support. 
and employment distributions where workers perform skilled but routine tasks, which leads to an increase in income inequality at the top end and a decrease at the low end.

- International trade: At the end of the $1990 \mathrm{~s}$, the consensus was that trade had only modest distributional effects. Even though the recent literature confirms that globalisation is not the most important factor behind the rise in inequality, it seems to have important implications for at least some groups of workers. In particular, offshoring appears to reduce employment and/or wages of medium-skilled workers performing routine tasks, thus reinforcing labour-market polarization. A growing body of literature at the firm-level suggests furthermore that firm heterogeneity is important for the way trade influences inequality.

- Immigration: A rather small impact on native workers and sizeable adverse wage or employment effects on the cohorts of previous immigrants are found, implying only small consequences for overall labour income inequality.

- Education: Wage inequality is negatively correlated with the average level of educational attainment, though the returns to education are higher at the top than at the bottom of the wage distribution and more dispersed among higher-educated workers.

- Labour market policies and institutions: The impact of declining unionisation and of the lower relative minimum wage is most pronounced at the lower end of the wage distribution while cross-country evidence suggests that government employment reduces wage inequality.

The remainder of this paper is structured as follows. Section 2 reviews the theoretical and empirical literature on skill-biased technological change. The subsequent two sections then investigate the role of globalisation, focusing on international trade flows (Section 3) and immigration (Section 4). ${ }^{2}$ The discussion of international trade flows will elaborate on both the traditional view that relies on the work by Heckscher and Ohlin and more recent views, including models of offshoring and firm heterogeneity. ${ }^{3}$ Sections 5 and 6 then explore the role of structural policy settings and institutions in shaping the distribution of labour income, focusing on education and labour markets. The survey draws mainly on the US literature, where developments have been studied in much more detail than for other countries and/or because advances in the literature have been made for this country in the first place. Yet, as much as possible evidence for other OECD countries is presented as well.

\section{Skill-biased technological change}

\subsection{The canonical view}

In the early 1990s, there was a wide consensus in the US literature that the rise in inequality that was observed during the 1980s was driven by an increase in the relative demand for skills, which, in turn, was attributed to skill-biased technological change (Lemieux, 2008). The traditional (canonical) model of skill-biased technological change assumes two distinct skill groups (high and low, typically college versus high school) that are imperfect substitutes. Skills, not tasks, are a direct input into production. In this framework, technology is factor-augmenting, always raises productivity and wages of both groups, and by complementing either high or low-skilled workers, can lead to skill-biased demand shifts that are either

2. For a recent discussion of the income inequality effects of political and social integration see Dreher and Gaston (2008). For a review of the literature on top incomes see Hoeller (2012) and for further discussions on the drivers of labour income inequality see Koske et al. (2012) and Fournier and Koske (2012).

3. For a comprehensive survey of the literature on trade and inequality see also Harrison et al. (2010) and for a survey of literature on globalisation and the labour market see Molnar et al. (2007). 
raising or reducing income inequality. If new technologies tend to increase the productivity of high-skilled workers more than that of low-skilled ones, then the wage of high-skilled workers should rise relatively faster. Skill-biased technological change increases the relative demand for skill in a rather monotonic manner across the wage distribution. However, the skill premium depends on the interaction between the demand for and supply of skills. There is a "race" between technology (inequality increasing) and education (inequality reducing): the premium will rise only if increases in the relative demand for skilled workers driven by technical progress are not offset by an increase in the relative endowment with skilled labour. In addition, the higher the elasticity of substitution between skilled and unskilled workers, the stronger will be the effect of skill-biased technical change and the lower the counteracting impact from skill upgrading.

The canonical model has been empirically quite successful in explaining the main stylised facts regarding changes in the college-high school wage gap in the United States. The skill premium increased moderately in the 1960s, declined in the 1970s, and expanded dramatically in the 1980s. In a seminal paper, Katz and Murphy (1992) showed that the estimation of a demand and supply framework can largely explain these variations as a result of steady demand growth in favour of better-educated workers and a flattening in the growth rate of the relative supply of college graduates. The latter slowed considerably after 1980 due to sluggish growth of educational attainment. As a result, technology has been racing ahead of education, leading to an increase in the returns to schooling and higher income inequality.

Subsequent research showed that the supply and demand framework captures salient features of the evolution in the returns to schooling even when the sample period is extended to 1940-96 (Autor et al., 1998), though it has been debated whether computers and the associated information technology advances have increased the demand for skills significantly more than other technologies did in the 1950s and 1960s (opposition between a steady-demand hypothesis and an acceleration hypothesis). In any case, a long-run shift towards up-skilling of workers characterised the entire twentieth century in the United States and the narrowing of the wage structure until the end of the 1970s came about largely because the supply of skills (rising educational attainment of successive cohorts) grew faster than did the demand for skills (Acemoglu, 2002; Goldin and Katz, 2007, 2008). ${ }^{4}$ Card and Lemieux (2001) enriched the canonical model by allowing for imperfect substitution among age cohorts to reflect differences in experience. When applied to the United States, the United Kingdom and Canada, the model can explain cross-country variations in the timing of the rise in the college-high school wage gap and within-country variation in the magnitude of the rise in the premium by age group. Moreover, Carneiro and Lee (2011) applied the model across US regions and extended the previous analysis by showing that not only changes in the supply of young college workers relative to old workers are important, but also changes in the quality of college graduates provide another composition effect that may affect the college premium.

However, there has been a fundamental criticism regarding the capacity of the canonical model to reflect changes in skill premia more recently. Although an augmented version of the Katz-Murphy model controlling for cyclical conditions and the real minimum wage performs well in explaining the growth of the college-high school wage premium in the United States between 1963 and 1992, the continued slow growth of relative supply after 1992 causes the model to significantly overpredict the increase in the premium since then (Autor et al., 2008). This pattern implies a slowdown in trend demand growth after 1992, which is inconsistent with a simple approach of skill-biased technical change given the rapid growth of ICT investment in the 1990s. Dustmann et al. (2009) find in the case of Germany that the supply and demand model performs poorly when a distinction is made only between skilled and unskilled labour,

4. However, the shift towards better-skilled workers was due to a fundamental change in the technological paradigm in the twentieth century: technical change was not skill-biased during the nineteenth century, and most likely, it was "deskilling" through a stronger division of labour and a simplification of tasks previously performed by artisans (Acemoglu, 2002). 
while a more fine-grained definition of skills leads to better results. Moreover, the relative wage gains have been disproportionately concentrated at the very top of the wage distribution in the United States (Piketty and Saez, 2003, 2006) and within-group or residual inequality (linked to unobservable characteristics) has grown substantially among college-educated workers, but changed little for most other groups (Lemieux, 2006a). Another difficulty with the standard approach is that while all economies were subject to the same technological advances, upper-tail inequality has increased steadily in English-speaking countries and has remained relatively unchanged in other economies such as France. Even though the relative supply of skills has increased faster in Europe, differences in changes in supply and demand is only one part of the explanation and a richer framework including the effects of labour market institutions and their impact on the nature of technical change is necessary (Acemoglu, 2003).

More importantly, despite its theoretical and empirical success, the canonical model of skill-biased technological change fails to account for several empirical developments over the last decades (Acemoglu and Autor, 2010): $i$ ) declining real wages of low-skilled workers, particularly low-educated males (at least in the United States); ii) marked wage polarisation, with non-monotonic changes in wage levels at different parts of the wage distribution characterised by a U-shaped pattern, that is a rise in inequality at the top end and a fall at the low end relative to the median wage; iii) the rising importance of occupation as a predictor of wages; $i v$ ) a "convexification" in the returns to education - that is wages have become an increasingly convex function of years of education (Lemieux, 2006b) - and possibly in the returns to other skills; $v$ ) widespread polarisation of employment by occupational skill marked by increases in employment in high-skilled and low-skilled occupations relative to middle-skilled occupations across advanced OECD countries; vi) rapid diffusion of new technologies that are directly skill-replacing (not augmenting), in particular that directly substitute capital for labour in tasks previously performed by moderately-skilled workers; and vii) expanding offshoring and outsourcing opportunities, enabled by technology, which allow foreign labour to substitute for domestic workers in certain occupations and tasks.

\subsection{The nuanced view}

More recently, theoretical and empirical research has amended the canonical model of skill-biased technological change, showing that a more nuanced approach is needed to account for the shifts in skill demands induced or abetted by the rapid price decline in computer technology over the last three decades (Acemoglu and Autor, 2010). The model underlying the nuanced view (also called the "routinisation" hypothesis) introduces an explicit distinction between tasks (a unit of activity that produces output) and skills (a worker's endowment of capabilities for performing various tasks), while occupations can be viewed as bundles of tasks. There are three types of skills - low, medium and high - and each worker is endowed with one of these types of skills. Skills do not directly produce output, but are applied to tasks to produce output. In this task-based framework, workers of a given skill level can perform a variety of tasks and the set of tasks they are assigned to can change in response to changes in labour market conditions and technology. However, depending on their level of skills, they have an absolute advantage in performing specific tasks. High-skilled workers have an advantage in performing "non-routine" abstract tasks (activities that require problem-solving, intuition, persuasion, creativity that are characteristic of professional, managerial, technical and creative occupations, such as law, medicine, science, engineering, design or management). Medium-skilled workers have an advantage in performing "routine" tasks that are based on precise and well-understood procedures (a characteristic of occupations such as book-keeping, clerical and administrative work, repetitive production or monitoring). Low-skilled workers have an advantage in performing "non-routine" manual tasks that require situational adaptability, visual and language recognition, and personal interactions (in particular, a characteristic of service occupations such as personal health assistance and of security and protective services).

In this framework, computerisation increases the relative demand for skills in a non-monotonic manner. Computers substitute for routine tasks (that can be readily formalised and "routinised" in 
computer code), complement non-routine abstract tasks, while non-routine manual tasks are not directly affected. ${ }^{5}$ The decline in the price of computers lowers the price of routine tasks and thus wages of workers for whom computers are a substitute and increases the demand for routine tasks. It also raises the marginal productivity of non-routine tasks, causing workers to reallocate labour supply from routine to non-routine manual and abstract tasks. This means that the increased demand for routine tasks is met by a higher investment in computer capital that more than offsets the decline in labour input, leading to a more "routine-task-intensive" economy. Computerisation depresses the relative wages of medium-skilled workers, both compared to high- and low-skilled workers, but has an ambiguous effect on wages of highly-skilled relative to low-skilled workers. If medium-skilled workers displaced by computers and machines are better substitutes for low- than highly-skilled workers, an assumption that appears plausible, then middle-skilled workers move downward in the task distribution. This puts greater downward pressure on low than highly-skilled wages and leads to a rise in wages at the top relative to the bottom of the wage distribution. ${ }^{6}$ Overall, task-replacing technology disproportionately affects medium-skilled workers and induces a polarisation or "hollowing out" in the distribution of wages and employment in the labour market.

The nuanced (task) view of skill-biased technological change has received strong empirical support for the United States. In a seminal paper, Autor et al. (2003) find that within industries, occupations, and education groups, computerisation is associated with reduced labour input of routine manual and cognitive tasks and increased labour input of non-routine cognitive tasks. Using data on task measures available from the Dictionary of Occupational Titles, they show that: $i$ ) shifts in labour input favouring non-routine against routine tasks were concentrated in rapidly computerising industries and started in the1970s; ii) task shifts away from routine and toward non-routine labour input are not mainly accounted for by educational upgrading as they are pervasive at all educational levels; iii) occupations that intensively computerised also experienced declines in routine cognitive tasks and increases in non-routine cognitive tasks. In a study of US employment structure trends. Autor et al. (2006) provide empirical evidence that employment growth by occupation shifted from monotonically increasing wages (education) in the 1980s to a pattern of employment polarisation in the 1990s marked by a more rapid growth in jobs at the top and bottom relative to the middle of the wage (education) distribution. They also find that in the 1990s employment growth by task content was most rapid for jobs intensive in non-routine abstract tasks, was declining at an increasing rate for occupations intensive in routine tasks and ceased declining for jobs intensive in non-routine manual tasks.

In a subsequent study Autor et al. (2008) show that even though real wage growth was essentially monotone (linear) by wage percentile in the 1980s (by declining at the lower end, stagnating around the median and expanding at the upper end), it was more U-shaped in the 1990s. In fact, wage changes by wage percentile and employment changes by skill percentile (proxied by educational levels) were positively correlated in the 1980s and 1990s, which is consistent with a demand-side explanation for observed wage changes. However, the growth of low-education, low-wage occupations accelerated between 1999 and 2007, with growth of employment heavily concentrated among the lowest three deciles (Acemoglu and Autor, 2010). Autor and Dorn (2010) find that the U-shaped pattern of wage and employment growth has also occurred within regional US labour markets, in particular in regions that were

5. Routine manual tasks are difficult to automate, thus technology affects them through its impact on other parts of the economy. At the same time, if the demand for them does not admit close substitutes, then substitution of information technology for routine tasks used in goods production can induce rising wages and employment in low skill service occupations (Autor and Dorn, 2010).

6. Performance pay is one channel through which this may happen. Lemieux et al. (2009) show that a rise in the demand for skills induces more firms to offer performance-pay contracts (because the market returns to effort and thus the benefits of implementing performance-pay systems increase) and results in more wage inequality among workers with performance-related pay. 
initially specialised in routine-intensive occupations, with the increase in wages at the lower end of the job and wage distributions mainly driven by service occupations. At the same time, adult workers displaced from middle-skilled to low-skilled occupations induce stronger competition in local labour markets that can reduce youth employment opportunities (Smith, 2008).

There is growing empirical evidence for other OECD countries that strongly supports the nuanced view of skill-biased technical change. Goos and Manning (2007) find that the pattern of employment changes in the United Kingdom over the period 1975-99 was marked by increases in the highest- and lowest-wage occupations, with job polarisation explaining one-third of the rise in the $\log (50 / 10)$ wage differential and one-half of the rise in the $\log (90 / 50)$. The "routinisation" hypothesis is found to be the main driving force of employment polarisation. Alternative hypotheses related to changes in the composition of labour supply (rising labour market participation of women, increase in educational attainment, changing age structure) are unable to explain it, while counterfactual simulations show that educational upgrading can only predict growth in "lovely" but not "lousy" jobs. Regarding changes in labour demand driven by factors other than technology, they suggest that trade is not necessarily a competing explanation to "routinisation" as jobs that can be routinised are the ones that are most likely to be shifted abroad.

Using a data set for West Germany to assess how skill requirements changed within occupations between 1979 and 1999, Spitz-Oener (2006) finds that there was a sharp increase in non-routine abstract tasks (such as doing research), a pronounced decline in routine tasks (such as double-entry bookkeeping) and growth in non-routine manual tasks leading to an overall pattern of "hollowing out" of middle-class occupations. Most of the task changes occurred within occupations, were most pronounced in rapidly computerising ones and cannot be explained by composition effects linked to education and age, as they also existed within occupation-education and within occupation-age groups. Even though they also happened within industries and occupations, routine tasks declined mainly for women and almost not at all for men, while women witnessed relative increases in non-routine abstract tasks. Moreover, these gender differences explained 50\% of the closing of the gender wage gap over the period (Black and Spitz-Oener, 2010). Dustmann et al. (2009) confirm the overall pattern of polarisation in employment growth in Germany between 1980 and 2000, but find that changes in employment and wages by wage percentile were negatively (positively) correlated below (above) the median, a result that contrasts with the positive correlation found for the United States throughout the entire distribution (Autor et al., 2008). This militates against a demand-based explanation of the rise in lower-tail inequality and can be better explained by other factors, in particular changes in labour market institutions (linked to de-unionisation) and the skill mix of the workforce in the 1990s.

Recent cross-country studies find that a pattern of polarisation of employment by skill level has been underway in many industrialised economies since at least the 1990s. Goos et al. $(2009,2010)$ study employment changes (weekly hours worked) in 21 broad occupation groups across 16 European countries. They find that in 15 countries, high-paying occupations expanded relative to middle-wage occupations in the 1990s and 2000s, and in all 16 countries, low-paying occupations expanded relative to middle-wage occupations. To identify the cross-country determinants of job polarisation, several variables are used: i) three measures of the types of tasks contained in an occupation (abstract, routine and service tasks) using the US Occupational Information Network database to test the "routinisation" hypothesis; ii) an average level of education in an occupation to test the canonical channel of skill-biased technical change; and iii) an index of offshorability using news reports about offshoring of European jobs from the European Restructuring Monitor to capture to what extent tasks done in different occupations are offshorable. They find that the evidence is the strongest for the "routinisation" hypothesis. The decrease in employment growth for offshorable occupations seems to be less pervasive and hence more country specific than the decrease linked to routinisation. 
Michaels et al. (2010) use 25 years of cross-industry data from the EUKLEMS database to show that information and communication technologies (ICT) were behind the polarisation of the labour markets in the United States, Japan and nine European countries over the period 1980-2004. They find that industries that experienced a faster growth of technical progress - proxied by ICT and R\&D investments - also had greater increases in demand for college-educated workers and this increase was mainly due to a reduction in the relative demand for middle-skilled rather than low-skilled workers. They also find a link between trade openness and polarisation, but it is not robust when controlling for technology.

\section{International trade}

\subsection{The Heckscher-Ohlin and Stolper-Samuelson theorems}

Early empirical studies on the link between trade and income inequality were typically motivated by the Heckscher-Ohlin model which predicts that countries export goods that use intensively the factor with which they are most abundantly endowed. Together with the Stolper-Samuelson theorem (which postulates that trade increases the real return to the factor that is relatively abundant), the framework implies that in countries that have a comparative advantage in producing high-skill-intensive goods, an opening up of trade should lead to an increase in labour income inequality by lowering wages and/or employment of low-skilled workers and raising those of high-skilled workers. The opposite should happen in countries abundant in unskilled labour.

The implications of the theorem, in particular the inequality-reducing effect of trade liberalisation in developing countries, have generally not been confirmed empirically (IMF, 2007; Goldberg and Pavcnik, 2007; Feenstra, 2008; Stone and Cavazos, 2011). Subsequent extensions (to more countries, a continuum of goods, or intermediate imported goods) have not led to robust empirical evidence either. Moreover, doubts have been raised as to whether the volume of trade between developed and developing countries is large enough to generate the observed increases in inequality - most of the volume of trade is still occurring between countries with similar endowments (Machin, 2008; Matano and Naticcioni, 2010).

\subsection{Offshoring}

Several new mechanisms have been explored through which trade can affect labour income inequality in a way that is more in line with the stylized facts. In particular, there was a significant focus on the effects of offshoring (or offshore outsourcing), a phenomenon that Blinder (2006) called the new Industrial Revolution. Feenstra and Hansen (1996) developed a model, in which a single good is produced by competitive firms using a continuum of tasks that can be ranked based on their skill intensity. The country where the good is produced is skill rich and outsources less skill-intensive tasks to a skill-poor country in order to minimize cost. If it becomes easier to offshore (modelled as a movement of capital from the skill-rich to the skill-poor country), more tasks are outsourced to the skill-poor country. These tasks are the least skill intensive performed in the skill-rich country, but are more skill intensive than the tasks initially done in the skill-poor country. Labour demand thus becomes more skill intensive in both countries and inequality increases in both of them.

The trade-in-tasks idea was further explored by Grossman and Rossi-Hansberg (2008) who developed a theoretical model in which technology induces a decline in the cost of offshoring that can have ambiguous effects on the wages of "routine" domestic workers. These will increase if the falling cost of offshoring (which acts as a positive productivity shock) is not fully offset by a deterioration in the home country's terms of trade (linked to a higher relative supply of the good produced) and an increase in the labour supply which puts downward pressure on wages (workers who formerly performed tasks that are subsequently carried out abroad have to be reabsorbed). Krugman (2008) developed a model of vertical specialisation in which exports of developing countries are concentrated in unskilled labour-intensive 
niches (such as assembly) within otherwise skilled labour-intensive sectors, such as computers and electronics. In this framework, the new ability of the North to outsource unskilled labour-intensive industry segments to the South can have distributional consequences through a Stolper-Samuelson-type effect, that is by increasing the real wages of skilled labour and reducing those of unskilled labour in the North.

Back-of-the-envelope calculations by Katz (2008) indicate that the effects put forth by Krugman (2008) are likely to be small. They can account for 15 to $19 \%$ (upper-bound estimate) of the increase in the college wage premium from 1980 to 2006 when using the estimates by Bivens (2007) that assume the distributional effects of trade to be essentially proportional to the import share, and between 6 to $12 \%$ (lower-bound estimate) when using the estimates of Lawrence (2008). Individual-level data for the United States confirm an only small impact of offshoring. Liu and Trefler (2008) look at the effect of offshoring of services to China and India between 1995 and 2005 and find negligible net effects on all variables of interest: $i$ ) changes in wages; $i$ ) weeks spent unemployed as a share of weeks in the labour force; and iii) occupation and industry switching. Ebenstein et al. (2009) use industry-level data for the manufacturing sector and find that within-industry effects of offshoring are small and can be ambiguous: they are negatively correlated with employment when the offshored activity is located in low-income locations, but positively when the location is in high-income countries. At the same time, wage effects on domestic workers are insignificant in the former case and slightly positive in the latter. However, wages and employment of workers in occupations where routine tasks dominate are the most affected by offshoring, a result consistent with the finding of Firpo et al. (2009b).

Yet, import competition leads to employment reallocation out of manufacturing to services and is associated with real wage declines that can be quite important for some occupations (Ebenstein et al., 2009). Another strand of literature has studied the distributional effects of foreign direct investment that can increase inequality by raising the relative return to skilled labour. Chintrakarn et al. (2010) find for the United States that inward FDI has insignificant effects on income inequality in the short run and reduces income inequality in the long run at the national level, but there is considerable heterogeneity in the long-run effects at the regional level (across states). However, regional policies geared to attract FDI can have a mitigating impact on inequality insofar as the demand for unskilled labour is increased locally (Driffield et al., 2010). Jaumotte et al. (2008) find evidence that technical progress and globalisation tend to increase the returns to skills, but that the contribution of technology to rising inequality is higher. The authors argue that two opposite globalisation effects operate: while financial globalisation (foreign direct investment in particular) tends to increase inequality, this is partly offset by a beneficial effect of increased trade. Yet, the latter study also shows considerable heterogeneity in the empirical results with globalisation reducing the dispersion of incomes in developing countries, and an opposite effect occurring in developed economies.

\subsection{Firm heterogeneity}

A number of theoretical papers have built on the work by Melitz (2003), who introduced monopolistic competition between heterogeneous firms into trade theory to explore the link between trade and labour income inequality. Egger and Kreickemeier (2009) introduce workers' preferences for fair wages into the model, assuming that the wage considered to be fair depends on the productivity and thus the economic success of the firm. They show that trade raises income inequality through both higher unemployment and a surge in within-group wage dispersion. Amiti and Davis (2011) also introduce fair wages into a Melitz-type model and also allow for trade in intermediate goods. They show that a decline in export tariffs reduces the wages of workers in domestically-oriented firms, but raises the wages of workers in exporting firms. Similarly, a fall in import tariffs raises the wages of workers in firms that use imported inputs, but reduces the wages of workers in firms that do not. Helpman et al. (2010) incorporate worker heterogeneity, search and matching frictions, and screening of workers by firms into a Melitz-type model. They conclude that the opening of a closed economy to trade raises unemployment and widens the dispersion of wages, 
but further increases in trade openness have an ambiguous effect on the wage distribution. Davis and Harrigan (2011) combine the model by Melitz (2003) with a variant of the efficiency-wage model by Shapiro and Stiglitz (1984). Workers can shirk on the job and need to be deterred from shirking by threatening them with dismissal in case they are caught. In contrast to the papers by Egger and Kreickemeier (2009) and Helpman et al. (2010) trade liberalization narrows the distribution of wages unless the probability of detecting a shirking worker is highly negatively correlated with the marginal product of labour. Verhoogen (2008) combines the ideas of Melitz (2003) with quality-differentiated goods. More productive (exporting) plants produce higher-quality goods and pay higher wages to maintain a higher-quality workforce. Yeaple (2005) follows a different approach to introduce firm heterogeneity than the papers that rely on the work by Melitz (2003). In his model homogenous firms choose a technology from a set of competing technologies and employees from a set of heterogeneous workers and the interaction between technology characteristics, international trade costs and worker heterogeneity gives rise to firm heterogeneity. A reduction in trade frictions induces firms to increase the wage premium paid to the most highly skilled workers and to reduce the wage premium paid to moderately skilled workers, thus raising wage dispersion.

The emerging empirical work on trade and inequality with firm-level data indicates that firm heterogeneity indeed matters for the way wages and employment react to trade liberalization. For example, Menezes-Filho and Muendler (2011) track individual workers in Brazil after the trade liberalization in the 1990s and find that trade liberalization is associated with a higher probability of transitioning into unemployment. Amiti and Davis (2011) show for Indonesia that trade liberalization raises wages of workers in globalized firms relative to workers in firms that are oriented towards the domestic market. Specifically, a 10 percentage point fall in export tariffs is found to lower wages by $3 \%$ in domestically-oriented firms and to raise wages in export-oriented firms by roughly the same amount. A 10 percentage point fall in import tariffs has no discernable effect on firms that do not import, but increases wages by up to $12 \%$ in firms that use imported inputs. Biscourp and Kramarz (2007) analyze the link between trade and employment for French manufacturing firms and find that importers of finished goods shed more jobs than importers of intermediate inputs, with the link being stronger for larger firms. Verhoogen (2008) shows for Mexican manufacturing plants that the 1994 peso crisis induced initially more productive firms to raise the wages of white-collar workers relative to the wages of blue-collar workers more than initially less-productive plants, and the relative wages of white-collar workers, increasing within-industry wage dispersion. A similar conclusion is reached by Kaplan and Verhoogen (2006). Brambilla et al. (2010) investigate the role of export destinations for wages in Argentinean manufacturing firms. They show that firms that export to high-income countries hire more skilled workers and pay higher wages than firms that export to middle-income countries or sell their goods in Argentina.

\subsection{Going beyond labour income}

The impact of trade on inequality in consumption may differ from its impact on labour income inequality. In particular, trade may mitigate the extent of the rise in inequality through a "price" effect of trade. Imports of low quality non-durable goods from developing countries such as China are consumed disproportionately by low-income households, which creates an inflation differential for different income groups (Broda and Romalis, 2008, 2009). Estimates for the United States over the period 1994-2005 show that non-durable inflation for the $10^{\text {th }}$ percentile of the income distribution has only been $0.4 \%$ per year, while it was $1.0 \%$ annually for the $90^{\text {th }}$ percentile. However, these results may also be partly driven by factors not related to trade but linked to increased competition in shopping outlets: the advent of supercenters (such as Wal-Mart) in a community leads to a significant reduction in prices and lower-income households tend to shop more at these low-price outlets (Hausman and Leibtag, 2007).

In addition to these price effects of trade liberalization, consumers might be affected through changes in the quality and variety of the goods they can purchase from their labour income. 
Fajgelbaum et al. (2009) develop a two-country model in which consumers have heterogeneous incomes and heterogeneous tastes and can choose the variety and the quality of a differentiated product. The two countries differ in their income dispersion and trade costs impede trade between the countries. The country with the more dispersed income distribution has a larger demand for high-quality goods and a smaller demand for low-quality goods. In this framework, a fall in tariffs lowers the price of low-quality goods in the country with the more dispersed wage distribution so that the demand for high-quality goods declines and the demand for low-quality goods rises. This induces the entry of firms that are producing low-quality goods and the exit of firms producing high-quality goods. This is more likely to benefit the poor than the rich as the former buy a greater fraction of low-quality goods and a smaller fraction of high-quality goods.

\section{Immigration}

The impact of immigration on average income should be negligible in the long run (as capital accumulates to restore the pre-migration capital-labour ratio), but the literature has focused on the effects on the relative income of native workers. ${ }^{7}$ This depends upon: $i$ ) the size of immigration flows; ii) substitutability between natives and immigrants; iii) relative abundance of natives in different education, skill, occupation and/or experience groups; and $i v$ ) integration of the "host" labour market with other markets (in the case of perfect integration there are no local effects due to general equilibrium impacts on the larger market). Following Card (1990), one strand of the literature relied on the use of natural experiments and difference-in-difference techniques across cities and/or states (so-called "area studies"). However, Borjas et al. (1997) argued that mobility rates are so sensitive to relative wages that inter-city comparisons are essentially uninformative. With the aim to provide a full picture of the adjustment of the labour market to immigration, Borjas (2003) popularised a structural labour market equilibrium approach by modelling aggregate production through a multi-level CES production function in which workers with different observable characteristics are imperfect substitutes.

Cross-city and cross-state evidence for the United States indicates small and often insignificant effects of immigration on the wages of native workers (Card, 1990; Butcher and Card, 1991; Card, 2001), as opposed to significant negative effects found when using national level data (Borjas et al., 1997; Borjas, 2003; Borjas and Katz, 2007). Focusing on the national market, Ottaviano and Peri $(2008,2012)$ raise serious objections to these empirical results and find that the competition effects of immigrants on wages of native workers in the United States are diluted through two channels: a high elasticity of substitution between workers with at most a high school degree and those without one; a small but significant degree of imperfect substitution between natives and immigrants. When allowing for the adjustment of capital, short- and long-run impacts of immigration on the wages of native workers with no high school degree and average native wages are small and positive, against a large significant negative wage effect of new immigrants on previous immigrants. Moreover, immigrants do not crowd-out employment of natives but add to total employment, increase total factor productivity significantly, and at the same time promote the adoption of unskilled-biased technology (Peri, 2009). Finally, Card and Shleifer (2009) find that immigration has very small impacts on wage inequality among natives, but when immigrants themselves are counted in the overall population, their presence can explain around 5\% of the increase in overall wage inequality in the United States between 1980 and 2000.

There is also a growing body of empirical literature about the impact of immigration on wages and employment in other leading OECD countries. As for the United States, the evidence for the United Kingdom suggests that immigration has a negligible impact on the wages of native-born workers and induces sizeable negative wage effects on previous immigrants (Manacorda et al., 2006). Comparable results, though also including employment effects, are found when considering the labour market impact of immigration in Western Germany in the 1990s. There is very little adverse effect on native workers' wages

7. For an assessment of the impact of immigration on the source country, see Koske et al. (2012). 
and on their employment and a sizeable adverse impact on previous immigrants (new and earlier immigrants are close to perfect substitutes) but, due to wage rigidities, mostly falling on employment rather than wages (D'Amuri et al., 2010). Yet other studies for Germany find that, when considering the level of education and experience, immigrants may reduce somewhat natives' wages, in particular in less-qualified occupations (Bonin, 2005; Steinhardt, 2011). Dustmann et al. (2008) also show for the United Kingdom that while migrants have a negative impact on lower wage quantiles, they have a positive one on middle and top quantiles.

The extent of labour and product market regulations may also affect the influence of immigration on labour market outcomes of natives. For a sample of fourteen Western European countries, D'Amuri and Peri (2011) find that immigration could positively affect the employment rates of natives, though they also identify changes in the occupational distribution of natives. Immigrants tend to take manual-routine type jobs while, in response, natives shift toward abstract-communication occupations and this reallocation is facilitated in countries with low employment protection legislation. Even though Jean and Jiménez (2011) cannot find a significant long-run impact of immigration on unemployment in OECD countries, they identify a temporary and delayed increase in natives' unemployment, in particular in countries with tight product market regulation and high replacement rates of unemployment benefits.

\section{Education}

The most basic theory linking education and the distribution of labour income is the human capital model by Schultz (1963), Ben-Porath (1967), Becker (1964, 1967) and Mincer (1974). Increases in an individual's human capital raise its productivity and, hence, its potential income. Individuals will therefore invest in formal schooling and on-the-job training as long as the costs of these investments (direct outlays for education and the opportunity cost of the time from not pursuing competing uses) do not exceed the expected income gains. Knight and Sabot (1983) propose a simple way to formalize the linkages between education and income inequality. They use a model with two groups of workers, low-educated (low-wage) workers and highly-educated (high-wage) workers. The effect of a rise in the share of highly-educated workers on income inequality can be thought of as the sum of two components. First, via a pure composition effect (i.e. holding rates of returns constant) it raises wage inequality up to a certain point (which will depend on the relative mean wages and the relative wage dispersions of the two groups) and will lower it thereafter. ${ }^{8}$ Second, it alters the relative returns to education with the direction of the change depending in particular on the degree of substitutability or complementarity between low- and highlyeducated workers. If low-educated and highly-educated workers are imperfect substitutes, then a fall in the number of low-educated workers and a rise in the number of highly-educated workers should raise the relative incomes of low-educated workers.

Teulings (2005) develops a model that allows a more differentiated analysis of the rate of return effects. In his model, there is a continuum of workers characterized by their skill level and a continuum of

8. This effect can itself be thought of as the sum of two separate effects: a) Assuming for simplicity that the wages of the two groups of workers are characterised by the same means but differing variances (with wages being more dispersed among highly-educated workers), starting from an economy where all workers have a low education level, an increase in the share of highly-educated workers raises economy-wide wage inequality in a monotonous way. b) Assuming instead for simplicity that wages of both low- and highly-educated workers are characterised by zero variances but differing means, starting from an economy where all workers have a low education level, an increase in the share of highly-educated workers first raises economy-wide wage inequality (as suddenly not all persons have the same wage anymore so that the variance of wages in the total economy becomes strictly positive), but eventually reduces it as fewer low-educated workers remain. Once all workers have reached a high level of education, the variance of wages goes back to zero. The relationship between the share of highly educated workers and inequality is thus inverted U-shaped. 
tasks characterized by their level of complexity. Better skilled workers are assumed to have a comparative advantage in complex jobs, implying that the substitutability of two workers is the lower, the further apart their skill levels are. The general equilibrium effects of an increase in the skill-level of the workforce can be decomposed into two parts. The first part, which always compresses the wage distribution, arises because an increase in the skill level of a worker from an arbitrary level $s_{1}$ to a higher level $s_{2}$ will increase the wages of workers that have a lower skill level than $s_{1}$ relative to workers that have a skill level higher than $s_{2}$. The second part arises because the additional human capital of the worker increases the production capacity. The extra capacity in the region between $s_{1}$ and $s_{2}$ lowers wages in that region. Slightly higher and slightly lower skilled workers are the best substitutes for these workers and, hence, their wages decline too, but by less than those of types $s_{1}$ and $s_{2}$. Based on this result Teulings (2005) argues that training programmes that aim at raising the relative wages of low-skilled workers should not be geared towards these workers themselves but to somewhat better-skilled workers as the low-skilled workers will benefit from the general equilibrium effects.

A number of recent studies have tried to link education policy and income inequality more directly. Sylwester (2002a) studies the impact of public education on income inequality. In his model public education can lower the level of income inequality provided that agents have sufficient resources to forgo income and attend school. If agents are too poor to attend school, then promoting public education can actually cause the distribution of income to become more skewed since the poor are taxed but do not enjoy the benefits of the public education system. Dur and Teulings (2002) explore the impact of education subsidies in a model where individuals are born with different levels of innate ability. Innate ability and the years of schooling jointly determine the human capital with which an individual enters the labour market. The authors show that when innate ability and education are complementary, education subsidies will lead to a widening of the income distribution because they disproportionately favour individuals with high innate ability as they take up most education. Using a slightly different model Hendel et al. (2005) also conclude that education subsidies can lead to higher income inequality. In their model, education is costly in terms of tuition and effort and the effort required is greater for low-ability persons. When households are credit-constrained, lack of education could mean either low ability or low financial resources. Firms can only observe an individual's education level but not ability, so that education has a signalling role. The wage of low-educated individuals reflects the mix of abilities: the smaller the proportion of high-ability individuals in the low-educated pool, the lower the wage of low-educated individuals. If education is made more affordable, more high-ability workers get a high education level and the quality of the low-educated pool drops, lowering the wage of low-educated individuals.

Given the theoretical ambiguities, the impact of education - and, hence, education policy - on labour income inequality ultimately remains an empirical issue. Owing to the lack of comprehensive education policy indicators, only few empirical studies have investigated the impact of education policy (rather than education outcomes) on income inequality. The main exception is education spending the inequality effects of which have been explored by a number of studies - with mixed results. For example, Sylwester (2002b) concludes that higher public spending on education is associated with lower income inequality (allocating an additional percentage point of GDP to public education is associated with a 1 percentage point drop in the Gini index), while Checchi (2000) draws the opposite conclusion. Hoxby (2008) looks specifically at redistributive school spending and finds for the United States that it reduces income inequality among adults, but that the effect is very small. The mixed results could be due to measurement problems because spending does not take into account the country-specific institutional setup and is a poor measure of the quality of the education system. Moreover, as the level of income inequality may influence the amount of public resources devoted to education, empirical studies have to deal with a reverse causality problem that is difficult to tackle in practice. The evidence is somewhat more clear-cut as regards the effect of education spending on the persistence of inequality across generations, i.e. intergenerational immobility. Most empirical studies indicate that intergenerational mobility is higher when education expenditure are higher 
and more equitably distributed, particularly at the elementary level (e.g. Björklund and Jantti, 2009; Mayer and Lopoo, 2008).

While the empirical literature on the link between education policy and income inequality is scant, the one on the link between education outcomes and income inequality is vast. Studies can be classified into two categories based on whether they rely on data at the country or household level. Studies that fall in the former category typically link a measure of income inequality (often a Gini index or decile ratio) to a measure of the average level of schooling and/or a measure of the dispersion of schooling outcomes. Using data across regions in the United States, Becker and Chiswick (1966) were the first to show that income inequality is negatively correlated with the average level of education and positively correlated with inequality in education. Subsequent studies have generally confirmed these findings for other countries and time horizons (e.g. Ahluwalia, 1976; Marin and Psacharopoulos, 1976; Winegarden, 1979). Looking at a broad set of countries over the period 1960 to 1990, De Gregorio and Lee (2002) find, for example, that an increase in one standard deviation in educational attainment reduces the Gini index by 3 percentage points, while an increase in educational dispersion by one standard deviation raises the Gini index by 2 percentage points. However, a significant proportion of the variation in income inequality across countries still remains unexplained.

Most of the more recent studies on the link between education and income inequality fall in the second category, i.e. they exploit household survey data. Studies that rely on quantile regression techniques generally find that the returns to education are higher at the top of the income distribution than at the bottom. Examples include: Machado and Mata (2001), Hartog et al. (2001) and Andini (2007) for Portugal; Budría and Moro-Egide (2008) for Spain; Fersterer and Winter-Ebmer (1999) for Austria; as well as Martins and Pereira (2004), Budría and Pereira (2005) and Prieto-Rodgriguez et al. (2008) for several European countries. This implies that wages are more dispersed among higher-educated workers, so that improvements in the education level of the workforce should be associated with an increase in inequality through the 'within' dimension. Prieto-Rodgriguez et al. (2008) show for a sample of 14 European countries that this 'within' component of wage inequality (i.e. wage inequality among equally educated people) is much more important than the 'between' component (i.e. wage inequality among groups with different education attainments). Martins and Pereira (2004) propose three potential explanations for the higher returns among high-income workers: $i$ ) lower wages of over-educated workers may increase the within-skill dispersion of pay by extending the lower tail of the wage distribution of highly educated workers; ii) if there is an interaction between innate ability and schooling, the role of ability differences within a given schooling level may be increasingly amplified in terms of pay as one considers high schooling levels; and iii) the bottom of the wage distribution may be over-represented with workers with low-level school quality or who engaged in fields of study that attract scarce interest in the labour market.

The evolution of returns to education over time appears to differ across countries. Lemieux (2006) shows for the United States that returns to post-secondary education have increased over time, with the increase larger for higher-income than for lower-income workers. He concludes that most of the growth in wage inequality between 1973 and 2005 was due to increases in the returns to post-secondary education, while increases in the returns to other characteristics such as experience, primary and secondary education only played a minor role. Machado and Mata (2001) reach the same conclusion for Portugal: the returns to education have increased most for those at the top of the income ladder. In Germany, by contrast, returns to education have been broadly stable over time (Prasad, 2004), while in Austria they have even fallen, particular the returns to university education (Fersterer and Winter-Ebmer, 1999). The fall in returns was most pronounced in the lowest quantiles; in the highest quantiles, returns remained almost constant. McGuinness et al. (2009) find for Ireland that the returns to education have been broadly stable among men, but started to decline among women towards the end of the 1990s, possibly due to strong demand for unskilled labour. 


\section{Labour market policies and institutions}

\subsection{The wage bargaining system}

In theory, the influence of the wage bargaining system on the dispersion of wages is ambiguous and depends on the number of workers who are covered by collective agreements (be it through union membership or through administrative extensions of collective agreements), the strength of unions as manifested in their wage effects, the level at which bargaining takes place (e.g. at the firm, industry or economy-wide level) and the degree of coordination.

Card et al. (2004) present a framework to analyse the impact of the first two factors on wage inequality. In this framework, the effect of unions on wage inequality is measured by the difference between the observed variance of wages and the variance that would prevail if all workers were paid their non-union potential wage. In the simplest version of the framework union status is assumed to be randomly assigned conditional on observed skill characteristics and the difference depends on three factors: $(i)$ a "within-sector" effect, which arises if the wages of the different skill groups are more or less dispersed under collective bargaining than in the absence of it; (ii) a "between-sector" effect, which reflects the wedge for each skill group between the average wage of union and non-union workers; and (iii) the variation of the union coverage rate and/or the union wage gain across skill groups.

Starting with the seminal paper by Freeman (1980), a wide range of studies have concluded that a higher share of workers affiliated to a trade union is associated with lower wage inequality (e.g. Card 1996; Gosling and Machin, 1995; Edin and Holmlund, 1995; Erickson and Ichino 1995; DiNardo et al., 1996; Machin, 1997; Kahn, 2000; Pontusson et al., 2002; Manacorda, 2004; Burniaux et al., 2006; Koeniger et al., 2007). However, the inequality-reducing effect of unions appears to apply predominantly to male workers (e.g. Card et al., 2004). A couple of studies investigate in more depth where in the wage distribution the effect takes place. It seems that union membership is most beneficial for the middle class. For example, Calderón et al. (2005) find for a sample of 121 countries that the effect of union membership on the poorest $20 \%$ is smaller and less robust than that on the middle class. Similarly, Firpo et al. (2009a) show that the wage effect of unions peaks around the $35^{\text {th }}$ quantile, meaning that middle-income workers benefit the most. In the top quintile, wages are actually reduced through higher union membership.

Several studies have tried to gauge the contribution of changes in union membership to changes in wage inequality. Most of them focus on the United States and find that a non-negligible part of the increase in wage inequality in the 1970s and 1980s can be attributed to a fall in union membership rates. For example, Card (1996) concludes that declining unionisation explains about one-fifth of the increase in the variance of male wages between 1973 and 1987. Extending the time horizon of the study to respectively 1993 and 2001, Card (2001) puts the effect at 15 to 20\% and Card etal. (2004) at 14\%. Di Nardo et al. (1996) show that about two-fifths of the increase in the 90/50 percentile ratio among male workers in the United States in the 1980s can be linked to a fall in unionization. Union membership rates fell much less in the 1990s then they did in the 1980s and, indeed, Card et al. (2004) argue that unions had very little impact on changes in wage inequality during the 1990s.

While the simple link between union membership rates and wage dispersion has been researched extensively, only a few studies investigate the role of the wage bargaining process, $e$.g. whether bargaining is centralized/coordinated or decentralized/uncoordinated. One prominent argument is that a centralized or coordinated bargaining process reduces inter-firm and inter-sectoral wage differentials as more firms or sectors are part of a single wage agreement. A necessary condition for this is that at least one of the parties involved aims at reducing such differences (Rowthorn, 1992). Centralization may also alter the distribution of power among actors. If the medium voter model applies, organizational politics may influence the wage demands of low-wage and high-wage unions in a way so as to compress the wage distribution (Pontusson 
et al., 2002). Wallerstein (1990) analyses the role of centralization versus decentralization on bargaining outcomes within a model with two groups of workers, each represented by an independent union. He shows that if a union maximizes a utilitarian welfare function with equal weights, centralized wage setting narrows the distribution of wages. The theoretical predictions are supported by most, but not all studies. For example, Checchi and García-Peñalosa $(2008,2010)$ find for panels of OECD countries that bargaining coordination reduces the $90 / 10$ percentile ratio. A similar conclusion is reached by Pontusson et al. (2002). They find a higher level of bargaining coordination is associated with lower wage inequality both in the upper and lower half of the wage distribution. Koeniger et al. (2007), by contrast, find that coordination reduces the $90 / 50$ percentile ratio but not the $50 / 10$ percentile ratio.

The inequality-reducing effect of unions that is associated with a more equal distribution of wages may at least partially be offset by lower employment. Strong trade unions may push wages above market-clearing levels, at the cost of lower employment, particularly among groups with a more elastic supply such as women, young and older workers (Bertola et al., 2002). In practice, the link between unionization and employment is more complex, depending on the structure of collective bargaining (Traxler, 2000). Decentralised wage bargaining at the firm level may prevent excessive wage claims (and hence adverse effects on employment) to not loose market shares to competitors, while centralised or coordinated bargaining systems may prevent excessive claims because unions internalise the adverse employment effects. Intermediate bargaining systems at the industry-level without higher-level coordination may thus yield the worst labour market outcomes (Calmfors and Driffill, 1988). Although a couple of studies have indeed found support for such a humped-shaped relationship between employment and corporatism (e.g. Scarpetta, 1996; Elmeskov et al., 1998; Bassanini and Duval, 2006), the literature remains inconclusive overall (for an overview, see Flanagan, 1999).

\subsection{Minimum wages}

A simple theoretical framework to think about the link between minimum wages and income inequality is provided by Teulings (2003). He assumes that a worker's human capital can be summarized in a single index so that the worker's wage is an increasing function of that index. Workers are imperfect substitutes and the substitutability of two workers declines with the distance between their levels of human capital. A rise in the minimum wage eliminates the left tail of the human capital distribution by pricing these workers out of the market. ${ }^{9}$ Firms that were employing such workers substitute towards workers that are the closest substitutes for the eliminated workers, i.e. workers with slightly higher human capital. This raises the wage of these workers slightly higher-skilled workers and induces firms that were employing these workers to substitute towards workers with even higher human capital. The rise in the minimum wage thus has two effects: the direct effect is the elimination of the left tail of the wage distribution and the indirect, general equilibrium effect leads to changes in relative wages. The general equilibrium effects are the largest just above the minimum wage level.

Much of the empirical literature on the effect of minimum wages on the dispersion of wages has focused on the United States. A consensus seems to have emerged that the fall in the real value of the minimum wage substantially contributed to the rise in wage inequality observed during the 1980s in the lower half of the wage distribution (e.g. DiNardo et al., 1996; Lee, 1999; Teulings, 2003; Lemieux, 2006). The fact that the 50/10 percentile ratio increased more for women than for men is consistent with the fact

9. The model abstracts from the possibility of monopsony power by firms. If firms have monopsony power, a rise in the minimum wage reduces the monopsonistic rent of employers, thereby increasing employment until the minimum wage reaches the wage level that would prevail in a perfectly competitive labour market. Only increases in the minimum wage beyond this level reduce employment. For a survey of other theoretical models in which a rise in the minimum wage may reduce unemployment under certain conditions and up to a certain level, see OECD (1998). 
that women are roughly twice as likely as men to be paid the minimum wage (Gordon and Dew-Becker, 2008). The positive relationship between the level of the minimum wage and wage inequality has recently also been confirmed for other countries (e.g. Dickens et al., 1999, for the United Kingdom; Calderón et al., 2005, for a panel of 121 countries; Checchi and García-Peñalosa, 2008, and Koeniger et al., 2007, for panels of OECD countries).

Whether an increase in the minimum wage raises income inequality through lower employment is still pretty much unsettled in the empirical literature. Some studies find that higher minimum wages reduce employment, in particular for lower-skilled workers, while others fail to detect any significant impact (a recent review of this literature is provided by Naumark and Wascher, 2007). The employment effects of a rise in the minimum wage are likely to depend on its level. However, such threshold effects have hardly been researched so far and no view has yet emerged as to the threshold above which the impact of a further increase in the minimum wage starts to bite in terms of lower employment.

\subsection{Government employment}

A few studies have investigated the role of government employment for wage inequality. The empirical evidence indicates that wages are more compressed in the public than in the private sector. Looking at a panel of 121 countries, Calderón et al. (2005) find that government employment reduces wage inequality, an effect that is mostly driven by sub-central levels of government. Pontusson et al. (2002) look at a sample of 156 OECD countries and conclude that public employment has egalitarian effects both in the upper and lower half of the wage distribution. The study by Koeniger et al. (2007) also points towards an inequality-reducing effect of public employment, though the authors use a rather crude proxy for public employment, namely the GDP share of public expenditure. In addition to reducing overall wage inequality, public employment seems to reduce inequality between men and women (e.g. García et al., 2001, for Spain; Grimshaw, 2000, for the United Kingdom).

The beneficial effects of public employment for the equality of wages may reflect that unions are more powerful in the public sector (e.g. Grimshaw, 2000; Checchi and Lucifora, 2002) or the purposeful use of public sector employment to achieve redistribution. Alesina et al. (2000) propose a model of public sector employment, in which the latter is not chosen solely based on efficiency considerations, but based on its redistributive impact. The authors show that under certain conditions of asymmetric information, politicians can claim that public projects are needed for efficiency, even though they are a disguised way of channeling resources to disadvantaged citizens when more explicit redistribution schemes would be politically opposed. The predictions of the model are empirically supported for the United States (Alesina et al., 2000) and Italy (Alesina et al., 2001). 


\section{BIBLIOGRAPHY}

Acemoglu, D. (2002), “Technical Change, Inequality, and the Labor Market”, Journal of Economic Literature, Vol. 40, No. 1, pp. 7-72.

Acemoglu, D. (2003), “Cross-Country Inequality Trends”, Economic Journal, Vol. 113, No. 485, pp. F121-F149.

Acemoglu, D. and D. Autor (2010), "Skills, Tasks and Technologies: Implications for Employment and Earnings", NBER Working Papers, No. 16082, National Bureau of Economic Research.

Ahluwahlia, M.S. (1976), "Income Distribution and Development: Some Stylized Facts", American Economic Review, Vol. 66, pp. 128-135.

Alesina, A., R. Baqir, and W. Easterly (2000), "Redistributive Public Employment", Journal of Urban Economics, Vol. 48, pp. 219-241.

Alesina, A., S. Danninger and M. Rostagno (2001), "Redistribution through Public Employment: The Case of Italy", IMF Staff Papers, Vol. 48, No. 3, pp. 447-473.

Amiti, M. and D.R. Davis (2011), "Trade, Firms, and Wages: Theory and Evidence", Review of Economic Studies, Vol. 79, No. 1, pp. 1-36.

Andini, C. (2007), "Within-Groups Wage Inequality and Schooling: Further Evidence for Portugal”, IZA Discussion Papers, No. 2828, Institute for the Study of Labor.

Autor, D. and D. Dorn (2010), "Inequality and Specialization: the Growth of Low-Skill Service Jobs and the Polarization of the U.S. Labor Market", NBER Working Paper, No. 15150, National Bureau of Economic Research.

Autor, D., F. Levy and R. Murnane (2003), “Empirical Exploration”, Quarterly Journal of Economics, Vol. 118, No. 4, MIT Press, pp. 1279-1333.

Autor, D., L. Katz and A. Krueger (1998), "Computing Inequality: Have Computers Changed the Labor Market?”, Quarterly Journal of Economics, Vol. 113, No. 4, MIT Press, pp. 1169-1213.

Autor, D., L. Katz and M. Kearney (2006), "The Polarization of the US Labour Market", American Economic Review, Vol. 96, No. 2, pp. 189-194.

Autor, D., L. Katz and M. Kearney (2008), “Trends in US Wage Inequality: Revising the Revisionists", Review of Economics and Statistics, Vol. 90, No. 2, pp. 300-323.

Bassanini, A. and R. Duval (2006), "Employment Patterns in OECD Countries: Reassessing the Role of Policies and Institutions", OECD Economics Department Working Papers, No. 486, OECD Publishing.

Becker, G.S. (1964), Human Capital, Columbia University Press for the National Bureau of Economic Research, New York. 
Becker, G.S. (1967), Human Capital and the Personal Distribution of Income: An Analytical Approach, University of Michigan.

Becker, G.S. and B.R. Chiswick (1966), "Education and the Distribution of Earnings", American Economic Review, Vol. 56, No. 2, pp. 358-369.

Ben-Porath, Y. (1967), "The Production of Human Capital and the Life Cycle of Earnings", Journal of Political Economy, Vol. 75, pp. 353-367.

Bertola, G., F. Blau and L. Kahn (2002), "Labor Market Institutions and Demographic Employment Patterns", NBER Working Papers, No. 9043, National Bureau of Economic Research.

Biscourp, P. and F. Kramarz (2007), "Employment, Skill Structure and International Trade: Firm-level Evidence for France”, Journal of International Economics, Vol. 72, No. 1, pp. $22-51$.

Bivens, J. (2007), "Globalization and American Wages: Today and Tomorrow”, EPI Briefing Paper, No. 196, Economic Policy Institute.

Björklund, A. and M. Jäntti, (2009), "Intergenerational Income Mobility and the Role of Family Background", Oxford Handbook of Economic Inequality, Oxford University Press.

Black, S. and A. Spitz-Oener (2010), "Explaining Women's Success: Technological Change and the Skill Content of Women's Work", Review of Economics and Statistics, Vol. 92, No. 1, MIT Press, pp. 187-194.

Blinder, A. (2006), “Offshoring: The Next Industrial Revolution?”, Foreign Affairs, No. 82, Vol. 2 , pp. 113-128.

Bonin, H. (2005), "Wage and Employment Effects of Immigration to Germany: Evidence from a Skill Group Approach", IZA Discussion Papers, No. 1875, Institute for the Study of Labor.

Borjas, G. (2003), "The Labor Demand Curve Is Downward Sloping: Reexamining the Impact of Immigration on the Labor Market", Quarterly Journal of Economics, Vol. 118, No. 4, MIT Press, pp. $1335-1374$.

Borjas, G. and L. Katz (2007), "The Evolution of the Mexican-Born Workforce in the United States", in: G. Borjas (ed.), Mexican Immigration to the United States, National Bureau of Economic Research, pp. 13-56.

Borjas, G., R. Freeman and L. Katz (1997), "How Much Do Immigration and Trade Affect Labor Market Outcomes?", Brookings Papers on Economic Activity, Vol. 1997, No. 1, Brookings Institution, pp. 1-90.

Brambilla, I., D. Lederman and G. Porto (2010), "Exports, Export Destinations and Skills", NBER Working Papers, No. 15995, National Bureau of Economic Research.

Broda, C. and J. Romalis (2008), "Inequality and Prices: Does China Benefit the Poor in America?", mimeo, University of Chicago.

Broda, C. and J. Romalis (2009), “The Welfare Implications of Rising Price Dispersion”, mimeo, University of Chicago.

Budría, S. and P.T. Pereira (2005), "The Impact of Educational Qualifications on Wage Inequality: Evidence for Europe", IZA Discussion Papers, No. 176, Institute for the Study of Labor. 
Budría, S. and A. Moro-Egido (2008), "Education, Educational Mismatch and Wage Inequality: Evidence for Spain," Economics of Education Review, Vol. 27, pp. 332-341.

Burniaux, J., F. Padrini and N. Brandt (2006), "Labour Market Performance, Income Inequality and Poverty in OECD Countries", OECD Economics Department Working Papers, No. 500, OECD Publishing.

Butcher, K. and D. Card (1991), "Immigration and Wages: Evidence from the 1980's", American Economic Review, Vol. 81, No. 2, pp. 292-296.

Caldéron, C., A. Chong and R. Valdés, (2005), "Labor Market Regulations and Income Inequality: Evidence for a Panel of Countries", in: J.E. Restrepo et al. (eds.), Labor Markets and Institutions, Chapter 7, pp. 221-279, Central Bank of Chile.

Calmfors, L. and J. Driffill (1988), "Bargaining Structure, Corporatism and Macroeconomic Performance", Economic Policy, Vol. 3, No. 6, pp. 13-61.

Card, D. (1990), "The Impact of the Mariel Boatlift on the Miami Labour Market", Industrial and Labor Relations Review, Vol. 43, No. 2, pp. 245-257.

Card, D. (1996), “The Effect of Unions on the Distribution of Wages: Redistribution or Relabelling?", Econometrica, Vol. 64, No. 4, pp. 957-980.

Card, D. (2001), "The Effect of Unions on Wage Inequality in the U.S. Labor Market", Industrial and Labor Relations Review, Vol. 54, No. 2, pp. 296-315.

Card, D. and A. Shleifer (2009), "Immigration and Inequality", American Economic Review: Papers and Proceedings, Vol. 99, No. 2, pp. 1-21.

Card, D. and T. Lemieux (2001), "Can Falling Supply Explain the Rising Return to College for Younger Men? A Cohort-based Analysis", Quarterly Journal of Economics, Vol. 116, No. 2, MIT Press, pp. 705-746.

Card, D., T. Lemieux and C. Riddell (2004), “Unions and Wage Inequality”, Journal of Labor Research, Vol. 25, pp. 519-562.

Carneiro, P. and S. Lee (2011) "Trends in Quality-adjusted Skill Premia in the United States, 1960-2000", American Economic Review, Vol. 101, No. 6, pp. 2309-2349.

Checchi, D. (2000), “Does Educational Achievement Help to Explain Income Inequality?”, Research Paper No. 208, World Institute for Development Economics Research.

Checchi, D. and C. Lucifora (2002), “Unions and Labour Market Institutions in Europe”, Economic Policy, Vol. 17, pp. 362-408.

Checchi, D. and C. García-Peñalosa (2008), "Labour Market Institutions and Income Inequality”, Economic Policy, Vol. 23, No. 56, pp. 601-649.

Checchi, D. and C. García-Peñalosa (2010), "Labour Market Institutions and the Personal Distribution of Income in the OECD", Economica, Vol. 77, No. 307, London School of Economics and Political Science, pp. 413-450.

Chintrakarn, P., D. Herzer and P. Nunnenkamp (2010), "FDI and Income Inequality: Evidence from a Panel of US States", Kiel Working Papers, No. 1579, Kiel Institute for the World Economy. 
D’Amuri, F. and G. Peri (2011), "Immigration, Jobs and Employment Protection: Evidence from Europe", NBER Working Papers, No. 17139, National Bureau of Economic Research.

D’Amuri, F., G. Ottaviano and G. Peri (2010), “The Labour Market Impact of Immigration in Western Germany in the 1990s", European Economic Review, Vol. 54, No. 4, Elsevier, pp. 550-570.

Davis, D.R. and J. Harrigan (2011), “Good Jobs, Bad Jobs, and Trade Liberalization”, Journal of International Economics, Elsevier, Vol. 84, No. 1, pp. 26-36.

De Gregorio, J. and J. Lee (2002), "Education and Income Inequality: New Evidence from Cross-Country Data", Review of Income and Wealth, Vol. 48, No. 3, pp. 395-416.

Dickens, R., S. Machin and A. Manning (1999), “The Effects of Minimum Wages on Employment: Theory and Evidence from Britain”, Journal of Labor Economics, Vol. 17, No. 1, pp. 1-22.

DiNardo, J., N.M. Fortin, and T. Lemieux (1996), "Labor Market Institutions and the Distribution of Wages, 1973-1992: A Semi-Parametric Approach”, Econometrica, Vol. 64, pp. 1001-1044.

Dreher, A. and N. Gaston (2008), "Has Globalization Increased Inequality", Review of International Economics, Vol. 16, No. 3, pp. 516-536.

Driffield, N., S. Girma, M. Henry and K. Taylor (2010), "Wage Inequality, Linkages and FDI", IZA Discussion Papers, No. 4722, Institute for the Study of Labor.

Dur, R. and C. Teulings (2002), "Education, Income Distribution and Public Policy", mimeo, Tinbergen Institute, Erasmus University, Rotterdam.

Dustmann, C., J. Ludsteck and U. Schönberg (2009), "Revisiting the German Wage Structure", Quarterly Journal of Economics, Vol. 124, No. 2, MIT Press, pp. 843-881.

Dustmann, C., T. Frattini and I. Preston (2008), "The Effect of Immigration on the Distribution of Wages", CReAM Discussion Paper, No. 03/08.

Ebenstein, A., A. Harrison, M. McMillan and S. Phillips (2009), "Estimating the Impact of Trade and Offshoring on American Workers Using the Current Population Surveys", NBER Working Papers, No. 15107, National Bureau of Economic Research.

Edin, P-A. and B. Holmlund (1995), "The Swedish Wage Structure: the Rise and Fall of Solidarity Wage Policy? ”, in R.B. Freeman and L.F. Katz (eds), Differences and Changes in Wage Structures, Chapter 9, University of Chicago Press, Chicago.

Egger, H. and U. Kreickemeier (2009), "Firm Heterogeneity and the Labor Market Effects of Trade Liberalization”, International Economic Review, Vol. 50, No. 1, pp. 187-216.

Elmeskov, J., J. Martin and S. Scarpetta (1998), "Key Lessons for Labour Market Reforms: Evidence from OECD Countries' Experiences”, Swedish Economic Policy Review, Vol. 5, No. 2, pp. 205-252.

Erickson, C.L. and A.C. Ichino (1995), "Wage Differentials in Italy: Market Forces, Institutions, and Inflation", in R.B. Freeman and L.F. Katz (eds.), Differences and Changes in Wage Structures, University of Chicago, Chicago Press.

Fajgelbaum, P., G.M. Grossman and E. Helpman (2009), "Income Distribution, Product Quality and International Trade," NBER Working Papers, No. 15329, National Bureau of Economic Research. 
Feenstra, R.C. (2008), "Offshoring in the Global Economy: Lecture 1: Microeconomic Structure; Lecture 2: Macroeconomic Implications," The Ohlin Lectures Presented at the Stockholm School of Economics, 17-18 September.

Feenstra, R.C. and G.H. Hanson (1996), "Foreign Investment, Outsourcing and Relative Wages", NBER Working Papers, No. 5121, National Bureau of Economic Research.

Fersterer, J. and R. Winter-Ebmer (1999), “Are Austrian Returns to Education Falling Over Time?”, IZA Discussion Papers 72, Institute for the Study of Labor.

Firpo, S., N. Fortin and T. Lemieux (2009a), "Unconditional Quantile Regressions”, Econometrica, Vol. 77, No. 3, pp. 953-973.

Firpo, S., N. Fortin and T. Lemieux (2009b), "Occupational Tasks and Changes in the Wage Structure", mimeo, September.

Flanagan, R.J. (1999), "Macroeconomic Performance and Collective Bargaining: An International Perspective", Journal of Economic Literature, Vol. 37, pp. 1150-1175.

Fournier, J.-M. and I. Koske (2012), "Less Income Inequality and More Growth - Are they Compatible? Part 7. The Drivers of Labour Earnings Inequality - An Analysis based on Conditional and Unconditional Quantile Regressions”, OECD Economics Department Working Papers, No. 930, OECD Publishing.

Freeman, R. (1980), "Unionism and the Dispersion of Wages", Industrial and Labor Relations Review, Vol. 34, No. 1, pp. 3-23.

Garcia, J., P.J. Hernandez and A. Lopez-Nicolas (2001), "How Wide Is the Gap? An Investigation of Gender Wage Differences Using Quantile Regression”, Empirical Economics, Vol. 26, pp. 149-167.

Goldberg, P. and N. Pavcnik (2007), "Distributional Effects of Globalization in Developing Countries", Journal of Economic Literature, Vol. 45, No. 1, pp. 39-82.

Goldin, C. and L. Katz (2007), "Long-run Changes in the U.S. Wage Structure: Narrowing, Widening, Polarizing”, NBER Working Papers, No. 13568, National Bureau of Economic Research.

Goldin, C. and L. Katz (2008), The Race between Education and Technology, The Belknap Press of Harvard University Press.

Goos, M. and A. Manning (2007), "Lousy and Lovely Jobs: The Rising Polarization of Work in Britain", Review of Economics and Statistics, Vol. 89, No. 1, pp. 118-133.

Goos, M., A. Manning and A. Salomons (2009), "The Polarization of the European Labour Market", American Economic Review: Papers and Proceedings, Vol. 99, No. 2, pp. 58-63.

Goos, M., A. Manning and A. Salomons (2010), "Explaining Job Polarization in Europe: the Roles of Technology and Globalization", CEP Discussion Papers, No. 1026, Centre for Economic Performance.

Gordon, R. and I. Dew-Becker (2008), "Controversies about the Rise of American Inequality: A Survey", NBER Working Papers, No. 13982, National Bureau of Economic Research.

Gosling, A. and S. Machin (1995), "Trade Unions and the Dispersion of Earnings in British Establishments", Oxford Bulletin of Economics and Statistics Vol. 57, pp. 167-84. 
Grimshaw, D. (2000), "Public Sector Employment, Wage Inequality and the Gender Pay Ratio in the UK", International Review of Applied Economics, Vol. 14, No. 4, pp. 427-448.

Grossman, G. and E. Rossi-Hansberg (2008), "Trading Tasks: A Simple Theory of Offshoring”, American Economic Review, Vol. 98, No. 5, pp. 1978-1997.

Harrison, A., J. McLaren and M.S. McMillan (2010), "Recent Findings on Trade and Inequality", NBER Working Papers, No. 16425, National Bureau of Economic Research.

Hartog, J., P.T. Pereira and J.A.C. Vieira (2001), "Changing Returns to Education in Portugal during the 1980s and early 1990s: OLS and Quantile Regression Estimators", Applied Economics, Vol. 33, pp. 1021-1037.

Hausman, J. and E. Leibtag (2007), "Consumer Benefits from Increased Competition in Shopping Outlets: Measuring the Effect of Wal-Mart", Journal of Applied Econometrics, Vol. 22, No. 7, pp. $1157-1177$.

Helpman, E., O. Itskhoki and S.J. Redding (2010), "Inequality and Unemployment in a Global Economy", Econometrica, Vol. 78, No. 4, pp. 1239-1283.

Hendel, I., J. Shapiro and P. Willen (2005), "Educational Opportunity and Income Inequality", Journal of Public Economics, Vol. 89, pp. 841-870.

Hoeller P. (2012), "Less Income Inequality and More Growth - Are they Compatible?: Part 4. Top Incomes", OECD Economics Department Working Papers, No. 927, OECD Publishing.

Hoxby, C.M. (2008), "School Spending, Income, and Inequality: The Efficient Redistribution Hypothesis", mimeo, Stanford University.

IMF (2007), World Economic Outlook - Globalization and Inequality, International Monetary Fund.

Jaumotte, F., S. Lall and C. Papageorgiou (2008), "Rising Income Inequality: Technology, or Trade and Financial Globalization?”, IMF Working Papers, No. 08/185.

Jean, S. and J. Jiménez (2011), "The Unemployment Impact of Immigration in OECD Countries", European Journal of Political Economy, Vol. 27, No. 2, pp. 241-256.

Kahn, L. (2000), "Wage Inequality, Collective Bargaining and Relative Employment from 1985 to 1994: Evidence from 15 OECD Countries", Review of Economics and Statistics, Vol. 82, No. 4, pp. 564-579.

Kaplan, D.S. and E.A. Verhoogen (2006), "Exporting and Individual Wage Premia: Evidence from Mexican Employer-Employee Data," unpublished paper, ITAM and Columbia University.

Katz, L. (2008), Comment on "Trade and Wages, Reconsidered" by P. Krugman, Brookings Papers on Economic Activity, Spring, Brookings Institution, pp. 143-149.

Katz, L. and K. Murphy (1992), "Changes in Relative Wages, 1963-1987: Supply and Demand Factors", Quarterly Journal of Economics, Vol. 107, No. 1, MIT Press, pp. 35-78.

Knight, J.B. and R.H. Sabot (1983), "Educational Expansion and the Kuznets Effect", American Economic Review, Vol. 73, No. 5, pp. 1132-1136. 
Koeniger, W., M. Leonardi and L. Nunziata (2007), "Labor Market Institutions and Wage Inequality", Industrial and Labor Relations Review, Vol. 60, No. 3, pp. 340-356.

Koske I., J-M. Fournier and I. Wanner (2012), "Less Income Inequality and More Growth - Are They Compatible? Part 2. The Distribution of Labour Income", OECD Economics Department Working Papers, No. 925, OECD Publishing.

Krugman, P. (2008), “Trade and Wages, Reconsidered”, Brookings Papers on Economic Activity, Vol. 39, No. 1, Brookings Institution, pp. 103-154.

Lawrence, R. (2008), “Blue-Collar Blues: Is Trade to Blame for Rising US Income Inequality?”, Policy Analyses in International Economics, Peterson Institute for International Economics, No. 85, Washington, D.C.

Lee, D. (1999), "Wage Inequality in the United States During the 1980s: Rising Dispersion or Falling Minimum Wage?”, Quarterly Journal of Economics, Vol. 114, No. 3, MIT Press, pp. 977-1023.

Lemieux, T. (2006a), "Increasing Residual Wage Inequality: Composition Effects, Noisy Data, or Rising Demand for Skill?”, American Economic Review, Vol. 96, No. 3, pp. 461-498.

Lemieux, T. (2006b), "Postsecondary Education and Increasing Wage Inequality", American Economic Review, Vol. 96, No. 2, pp. 195-199.

Lemieux, T. (2008), “The Changing Nature of Wage Inequality", Journal of Population Economics, Vol. 21, No. 1, pp. 21-48.

Lemieux, T., W.B. MacLeod and D. Parent (2009), "Performance Pay and Wage Inequality", The Quarterly Journal of Economics, Vol. 144, No. 1, MIT Press, pp. 1-49.

Liu, R. and D. Trefler (2008), "Much Ado About Nothing: American Jobs and the Rise of Service Outsourcing to China and India", NBER Working Papers, No. 14061, National Bureau of Economic Research.

Machado, J.A.F. and J. Mata (2001), "Earning Functions in Portugal 1982-1994: Evidence from Quantile Regressions”, Empirical Economics, Vol. 26, No. 1, pp. 115-134.

Machin, S. (1997), "The Decline of Labour Market Institutions and the Rise in Wage Inequality in Britain”, European Economic Review, Vol. 41, No. 3-5, Elsevier, pp. 647-657.

Machin, S. (2008), “An Appraisal of Economic Research on Changes in Wage Inequality”, Labour, Vol. 22, pp. 7-26.

Manacorda, M. (2004), "Can the Scala Mobile Explain the Fall and Rise of Earnings Inequality in Italy? A Semiparametric Analysis, 1977-1993”, Journal of Labor Economics, Vol. 22, No. 3, pp. 585-613.

Manacorda, M., A. Manning and J. Wadsworth (2006), "The Impact of Immigration on the Structure of Male Wages: Theory and Evidence from Britain”, CReAM Discussion Paper Series, No. 0608, University College London.

Marin, A. and G. Psacharopoulos (1976), "Schooling and Income Distribution", The Review of Economics and Statistics, MIT Press, Vol. 58, No. 3, pp. 332-338.

Martins, P.S. and P.T. Pereira (2004), "Does Education Reduce Wage Inequality? Quantile Regressions Evidence from Fifteen European Countries”, Labour Economics, Vol. 11, No. 3, pp. 355-371. 
Matano, A. and P. Naticchioni (2010), "Trade and Wage Inequality: Local versus Global Comparative Advantages", The World Economy, Wiley Blackwell, Vol. 33, No. 12, pp. 1757-1787.

Mayer, S.E. and L.M. Lopoo (2008), "Government Spending and Intergenerational Mobility", Journal of Public Economics, Vol. 92, No. 1-2, pp. 139-158.

McGuinness, S., F. McGinnity and P.J. O'Connell (2009), "Changing Returns to Education during a Boom? The Case of Ireland", Labour, Vol. 23, pp. 197-221.

Melitz, M. (2003), "The Impact of Trade on Intra-industry Reallocations and Aggregate Industry Productivity," Econometrica, Vol. 71, pp. 1695-1725.

Menezes-Filho, N.A. and M.-A. Muendler (2011), "Labor Reallocation in Response to Trade Reform," NBER Working Papers, No. 17372, National Bureau of Economic Research.

Michaels, G., A. Natraj and J. Van Reenen (2010), "Has ICT Polarized Skill Demand? Evidence from Eleven Countries over 25 Years", NBER Working Papers, No. 16138, National Bureau of Economic Research.

Mincer, J. (1974), Schooling, Experience, and Earnings, Columbia University Press for the National Bureau of Economic Research, New York.

Molnár, M., N. Pain and D. Taglioni (2007), “The Internationalisation of Production, International Outsourcing and Employment in the OECD", OECD Economics Department Working Papers, No. 561, OECD Publishing.

Neumark, D. and W. Wascher (2007), "Minimum Wages and Employment", IZA Discussion Papers, No. 2570, Institute for the Study of Labor.

OECD (1998), OECD Employment Outlook, June, OECD Publishing.

Ottaviano, G. and G. Peri (2008), "Immigration and National Wages: Clarifying the Theory and the Empirics”, NBER Working Papers, No. 14188, National Bureau of Economic Research.

Ottaviano, G. and G. Peri (2012), "Rethinking the Effects of Immigration on Wages", Journal of the European Economic Association, Vol. 10, No. 1, pp. 152-197.

Peri, G. (2009), “The Effect of Immigration on Productivity: Evidence from US States”, NBER Working Papers, No. 15507, National Bureau of Economic Research.

Piketty, T. and E. Saez (2003), "Income Inequality in the United States, 1913-1998”, Quarterly Journal of Economics, Vol. 118, No. 1, MIT Press, pp. 1-39.

Piketty, T. and E. Saez (2006), "The Evolution of Top Incomes: A Historical and International Perspective", American Economic Review, Vol. 96, No. 2, pp. 200-205.

Pontusson, J., D. Rueda and C. Way (2002), "Comparative Political Economy of Wage Distribution: The Role of Partisanship and Labour Market Institutions", British Journal of Political Science, Vol. 32, No. 2, pp. 281-308.

Prasad, E.S. (2004), "The Unbearable Stability of the German Wage Structure: Evidence and Interpretation", IMF Staff Papers, Vol. 51, pp. 354-385.

Prieto-Rodriguez, J., C.P. Barros, and J. Vieira (2008), "What a Quantile Approach can Tell Us about Returns to Education in Europe?”, Education Economics, Vol. 16, pp. 391-410. 
Rowthorn, B. (1992), "Corporatism and Labour Market Performance”, in: J. Pekkarinen, M. Pohjola and B. Rowthorn (eds.), Social Corporatism, Clarendon Press, Oxford, pp. 82-131.

Scarpetta, S. (1996), "Assessing the Role of Labour Market Policies and Institutional Settings on Unemployment: A Cross-Country Study”, OECD Economic Studies, Vol. 26, OECD Publishing, pp. 43-98.

Schultz (1963), The Economic Value of Education, Columbia University Press, New York.

Shapiro, C. and J.E. Stiglitz (1984), "Equilibrium Unemployment as a Worker Discipline Device", American Economic Review, Vol. 74, No. 3, pp. 433-44.

Smith, C. (2008), "Implications of Adult Labor Market Polarization for Youth Employment Opportunities", mimeo, July, MIT.

Spitz-Oener, A. (2006), "Technical Change, Job Tasks, and Rising Education Demand: Looking Outside the Wage Structure”, Journal of Labour Economics, Vol. 24, No. 2, pp. 235-270.

Steinhardt, M.F. (2011), "The Wage Impact of Immigration in Germany - New Evidence for Skill Groups and Occupations", The B.E. Journal of Economic Analysis and Policy, Vol. 11, No. 1, Article 31.

Stone, S. and R. Cavazos (2011), "Wage Implications of Trade Liberalisation: Evidence for Effective Policy Formation", OECD Trade Policy Working Papers, No. 122, OECD Publishing.

Sylwester, K. (2000a), “A Model of Public Education and Income Inequality with a Subsistence Constraint”, Southern Economic Journal, Vol. 96, pp. 144-158.

Sylwester, K. (2002b), “Can Education Expenditures Reduce Income Inequality?”, Economics of Education Review, Vol. 21, pp. 43-52.

Teulings, C.N. (2003), "The Contribution of Minimum Wages to Increasing Wage Inequality", Economic Journal, Vol. 113, No. 490, pp. 801-833.

Teulings, C.N. (2005), "Comparative Advantage, Relative Wages, and the Accumulation of Human Capital", Journal of Political Economy, Vol. 113, pp. 425-461.

Traxler, F. (2000), "The Bargaining System and Performance: A Comparison of 18 OECD Countries", Comparative Political Studies, Vol. 33, No. 9, pp. 1154-1190.

Verhoogen, E.A. (2008), “Trade, Quality Upgrading, and Wage Inequality in the Mexican Manufacturing Sector", Quarterly Journal of Economics, Vol. 123, MIT Press, pp. 489-530.

Wallerstein, M. (1990), "Centralized Bargaining and Wage Restraint”, American Journal of Political Science, Vol. 43, pp. 982-1004.

Winegarden, C.R. (1979), "Schooling and Income Distribution: Evidence from International Data", Economica, Vol. 46, pp. 83-87.

Yeaple, S.R. (2005), “A Simple Model of Firm Heterogeneity, International Trade, and Wages," Journal of International Economics, Vol. 65, pp. 1-20. 


\section{WORKING PAPERS}

The full series of Economics Department Working Papers can be consulted at www.oecd.org/eco/workingpapers/

930. Less income inequality and more growth - Are they compatible?

Part 7. The drivers of labour earnings inequality - An analysis based on conditional and unconditional quantile regressions

(January 2012) by Jean-Marc Fournier and Isabell Koske

929. Less income inequality and more growth-Are they compatible?

Part 6. The distribution of wealth

(January 2012) by Kaja Bonesmo Fredriksen

928. Less income inequality and more growth-Are they compatible?

Part 5. Poverty in OECD countries

(January 2012) by Mauro Pisu

927. Less income inequality and more growth-Are they compatible?

Part 4. Top incomes

(January 2012) by Peter Hoeller

926. Less income inequality and more growth-Are they compatible?

Part 3. Income redistribution via taxes and transfers across OECD countries

(January 2012) by Isabelle Joumard, Mauro Pisu and Debbie Bloch

925. Less income inequality and more growth-Are they compatible?

Part 2. The distribution of labour income

(January 2012) by Isabell Koske, Jean-Marc Fournier and Isabelle Wanner

924. Less income inequality and more growth-Are they compatible?

Part 1. Mapping income inequality across the OECD

(January 2012) by Peter Hoeller, Isabelle Joumard, Mauro Pisu and Debbie Bloch

923. Current issues in managing government debt and assets

(December 2011) by Eckhard Wurzel and Lukasz Rawdanowicz

922. Public spending efficiency in the Czech Republic: fiscal policy framework and the main spending areas of pensions and healthcare

(December 2011) by Zuzana Smidova

921. Exploring determinants of subjective wellbeing in OECD countries - evidence from the World Value Survey

(December 2011) by Sarah Fleche, Conal Smith and Piritta Sorsa

920. Russia: progress in structural reform and framework conditions

(December 2011) by Yana Vaziakova, Geoff Barnard and Tatiana Lysenko

919. Explaining the interest-rate-growth differential underlying government debt dynamics

(December 2011) by David Turner and Francesca Spinelli 
918. Reassessing the NAIRUs after the crisis

(December 2011) by Stéphanie Guichard and Elena Rusticelli

917. Employment protection legislation and plant-level productivity in India

(December 2011) by Sean Dougherty, Verónica Frisancho Robles and Kala Krishna

916. Systemically important banks and capital regulation challenge

(December 2011) by Patrick Slovik

915. Improving educational outcomes in Slovenia

(December 2011) by Mehmet Eris

914. Addressing challenges in the energy sector in Israel

(December 2011) by Philip Hemmings

913. Issues in private sector finance in Israel

(December 2011) by Philip Hemmings

912. How to improve the economic policy framework for the housing market in Israel (December 2011) by Philip Hemmings

911. Fiscal Prospects and Reforms in India

(December 2011) by Richard Herd, Sam Hill and Vincent Koen

910. Structural reforms to reduce unemployment and restore competitiveness in Ireland (December 2011) by Álvaro Pina

909. Getting back on track: restoring fiscal sustainability in Ireland

(December 2011) by David Haugh

908. A welfare analysis of climate change mitigation policies

(November 2011) by Alain de Serres and Fabrice Murtin

907. Overcoming the banking crisis in Ireland

(November 2011) by Muge Adalet McGowan

906. Macroeconomic and structural policies to further stabilise the Mexican economy

(November 2011) by Cyrille Schwellnus

905. Reaping the benefits of a transition to greener growth in Slovakia

(November 2011) by Caroline Klein

904. Fiscal reform for a stronger fairer and cleaner Mexican economy

(October 2011) by Nicola Brandt and Rodrigo Paillacar

903. The demand for safe assets in emerging economies and global unbalances: new empirical evidence (October 2011) by Rudiger Ahrend and Cyrille Schwellnus 